\title{
KESIAPAN ANAK MASUK SEKOLAH DASAR DITINJAU DARI TINGKAT INTELIGENSI DAN JENIS KELAMIN
}

\author{
Andia Kusuma Damayanti, Rachmawati \\ Fakultas Psikologi, Universitas Wisnuwardhana \\ email: budamayanti@yahoo.com, sijelitarach@yahoo.com
}

\begin{abstract}
ABSTRAK: Penelitian ini bertujuan untuk menguji hipotesa perbedaan kesiapan anak masuk sekolah dasar ditinjau dari tingkat inteligensi dan jenis kelamin.Subjek penelitian siswa TK Al - Jabbar dan TKIT Robbani di Malang sejumlah 76 dengan metode purposive random sampling. Kesiapan bersekolah menggunakan Nijmeegse Schoolbekwaamheids Test (NST), tingkat inteligensi dengan tes kecerdasan yaitu WISC (Wechler Intelegence Scale for Children) serta Jenis Kelamin diambil dari data siswa.Hasil olah statistik dari data penelitian menunjukkan nilai chi-square Hitung 58,106 > chi-square Tabel 5,991, bahwa ada perbedaan rata-rata kesiapan anak masuk sekolah dasar ditinjau dari tingkat kecerdasan dan jenis kelamin.Data penelitian ini dianalisis dengan teknik teknik uji Friedman Test.
\end{abstract}

Kata kunci : NST; WISC; Tingkat Kecerdasan, Jenis Kelamin

ABSTRACT: This study aims to test the hypothesis of differences in the readiness of children entering elementary school in terms of their level of intelligence and gender. The research subjects of TK Al - Jabbar and TKIT Robbani students in Malang were 76 with purposive random sampling method. Readiness to go to school using NST (Nijmeegse School barbamidsids Test), intelligence level with intelligence tests namely WISC (Wechler Intelegence Scale for Children) and Gender taken from student data. Results of statistics from the research data show 58,106 count chi-square values $>$ Chi-square Table 5,991, that there is a difference in the average readiness of children entering elementary school in terms of their level of intelligence and sex. The data of this study were analyzed using the Friedman Test technique.

Keywords: NST; WISC; Intelligence Level, Gender

\section{PENDAHULUAN}

Pendidikan anak usia dini (PAUD) adalah jenjang pendidikan sebelum jenjang pendidikan dasar yang merupakan suatu upaya pembinaan yang ditujukan bagi anak sejak lahir sampai dengan usia enam tahun yang dilakukan melalui pemberian rangsangan pendidikan untuk membantupertumbuhan dan perkembangan jasmani dan rohani agar anak memiliki kesiapan dalam memasuki pendidikan lebih lanjut, yang diselenggarakan pada jalur formal, nonformal, dan informal. 
Masa kanak-kanak dimulai pada akhir masa bayi sampai saat anak-matang secara seksual. Jadi mulai sekitar umur 2 tahun sampai sekitar umur 12 tahun, ada sebagian anak yang baru berumur 11 tahun sudah tidak termasuk kanak-kanak, tetapi ada juga yang sudah berumur 14 tahun masih termasuk masa kanak-kanak. Jadi tidak dapat dipastikan hanya sekitar usia itu. Masa kanak-kanak dibagi menjadi dua periode, yaitu awal masa kanak-kanak, sekitar umur 2 tahun - 6 tahun, dan akhir masa kanak-kanak sekitar umur 6 tahun 12 tahun. Usia ini ditandai dengan mulainya anak masuk sekolah dasar yang merupakan sejarah baru dalam kehidupannya yang kelak akan mengubah sikap-sikap dan tingkah lakunya (Damayanti,2016).

Hasil penelitian Andia Kusuma Damayanti (2015) menyatakan bahwa bahwa 1) bahwa pada kesiapan anak masuk SD jika ditinjau dari dukungan orangtua ada perbedaan. Hal ini dibuktikan dari $\mathrm{F}=$
40,694; $p>0,01$. Hal ini berarti anak yang mempunyai dukungan dari orangtua dalam kesiapan bersekolahnya lebih baik daripada anak yang tidak mendapat dukungan dari orangtua. 2) pada kesiapan anak masuk SD jika ditinjau dari motivasi belajar ada perbedaan. Hal ini dibuktikan dari $\mathrm{F}=$ 41.639; $\mathrm{p}<0,01$. Hal ini berarti anak yang mempunyai motivasi belajar lebih baik kesiapan bersekolahnya dibanding anak yang tidak mempunyai motivasi belajar.

Terkait dengan kesiapan sekolah, Hurlock (1980) menyatakan bahwa kesiapan bersekolah terdiri dari kesiapan secara fisik dan psikologis, yang meliputi kesiapan emosi, sosial dan intelektual. Seorang anak dikatakan telah memiliki kesiapan fisik bila perkembangan motoriknya sudah matang, terutama koordinasi antara mata dengan tangan (visio-motorik) berkembang baik.

Definisi kesiapan anak untuk sekolah telah mengalami perubahan besar selama empat dekade terakhir. Itu telah 
berubah dari terutama definisi kedewasaan untuk konsep yang dibangun secara sosial. Pendekatan terdahulu menekankan tingkat kedewasaan anak yang memungkinkan pekerjaan yang tenang dan fokus sebagai indikator utama kesiapan sekolah (Gesell, Ilg dan Ames 1974; Pandis 2001). Pendekatan yang lebih baru menekankan stres dua arah antara anak dan lingkungannya (Murphy dan Burns 2002). Sebagai per perspektif yang lebih baru ini, itu adalah 'kebaikan yang sesuai' antara anak dan lingkungan yang mendukung dan mempromosikan pengembangan optimal (Graue 1992; Meisels 1995). Dengan kata lain, kesiapan sekolah adalah produk dari interaksi antara anak dan kisaran pengalaman lingkungan dan budaya yang memaksimalkan hasil perkembangan untuk anak-anak (Unicef, 2012).

Pernyataan misi World Fit for

Children (WFFC) PBB tahun 2002 adalah sangat baik yaitu contoh konsep kesiapan sekolah yang lebih mutakhir, yaitu, awal yang baik dalam hidup, dalam memelihara dan lingkungan yang aman yang memungkinkan anak-anak untuk bertahan hidup dan sehat secara fisik, waspada secara mental, aman secara emosional, kompeten secara sosial dan mampu belajar. Tujuan WFFC menyoroti pentingnya lingkungan yang peduli, aman, dan merangsang secara holistik perkembangan anak-anak (Unicef,2012).

Pengalaman pendidikan sebelum sekolah dasar bervariasi dan berbeda di seluruh dunia (UNESCO 2007). Tetapi mereka memiliki satu kesamaan karakteristik: Sebagian besar program perawatan anak usia dini dan pendidikan sangat berbeda dibandingkan dengan filosofi pendidikan, gaya pengajaran dan struktur sekolah dasar. Menciptakan kesinambungan dan mempertahankan harapan belajar untuk anak-anak antara pembelajaran awal dan lingkungan sekolah dasar adalah karakteristik yang menentukan sekolah siap (Lombardi 1992). 
Semakin besar kesenjangan antara sistem perawatan dan pendidikan anak usia dini dan sistem sekolah dasar, semakin besar tantangan bagi anak-anak untuk beralih dari pembelajaran awal ke lingkungan sekolah dasar (Unicef, 2012). Hal senada juga dikemukakan oleh Byrnes, pendidikan anak usia dini akan memberikan persiapan anak menghadapi masa-masa ke depannya, yang paling dekat adalah menghadapi masa sekolah. "Saat ini, beberapa taman kanakkanak sudah meminta anak murid yang mau mendaftar di sana sudah bisa membaca dan berhitung. Di masa TK pun sudah mulai diajarkan kemampuan bersosialisasi dan problem solving. Oleh karena kemampuan-kemampuan itu sudah bisa dibentuk sejak usia dini. Pendidikan anak usia dini itu penting, karena di usia inilah anak membentuk pendidikan yang paling bagus. Di usia inilah anak-anak harus membentuk kesiapan dirinya menghadapi masa sekolah dan masa depan. Investasi terbaik yang bisa Anda berikan untuk anak-anak adalah persiapan pendidikan mereka di usia dini (belajarpsikologi.com/pentingnyapendidikan-anak-usia-dini/diakses tgl 03 Agustus 2018).

Menurut Denton (2000), Schoen dan Nagle (2004) sikap terhadap pembelajaran, seperti kegigihan tugas, perhatian, kreativitas, inisiatif, rasa ingin tahu dan penyelesaian masalah, juga dikenal penting untuk kesiapan sekolah. Berdasarkan konsep-konsep ini, kesiapan sekolah adalah cara holistik dalam melihat kesiapan anak-anak untuk sekolah. Tidak terbatas pada satu bidang pengembangan atau fungsi, kesiapan mencakup keterkaitan antara keterampilan dan perilaku di seluruh domain pengembangan dan pembelajaran (Unicef, 2012).

Menurut Prianto (2011) memang, tidak dapat disangkal bahwa kemampuan membaca, menulis dan berhitung amat dibutuhkan di SD. Namun, mempersiapkan anak untuk menekuni pendidikannya di SD 
bukanlah semata-mata ia sudah harus bisa membaca, menulis, dan berhitung saja, karena sebenarnya masih banyak lagi kemampuan lain yang perlu dipersiapkan sebelum anak masuk SD. Sikap-sikap seperti tidak bergantung pada ibu atau nenek atau si mbak yang menunjukkan bagaimana kemandirian anak; mau berbagi dengan teman; mau bersosialisasi alias bergaul dengan teman lain; tidak malu; dan lain-lainnya, justru lebih diperlukan oleh ananda yang akan masuk SD. Jadi, agar anak siap masuk SD, diperlukan kesiapan dalam seluruh aspek perkembangannya, dari fisik, kecerdasan, sosial-emosional, hingga bahasa. Bahwa usia bukan merupakan satu-satunya hal yang menentukan kesiapan atau kematangan seorang anak. Oleh karena itu ketika kita mulai memikirkan si kecil untuk masuk SD, maka kita perlu memahami ciri-ciri dari anak yang siap untuk sekolah. Adapun ciri-ciri anak siap masuk sekolah adalah sebagai berikut : 1) dilihat perkembangan fisiknya, 2) dalam menggambar, 3) ketergantungan pada ibu-ayah atau orang dewasa lain mulai berkurang, 4) anak sangat menyukai kegiatan yang dipilih sendiri dan ia sangat menikmatinya, 5) anak mulai lebih bisa berkonsentrasi dan memusatkan perhatiannya pada satu hal, 6) anak dapat berbagi dan bermain bersamasama dengan temannya, 7) anak senang berbicara, pertanyaan anak juga sudah lebih rumit.

$$
\text { Studi longitudinal mengenai }
$$
kecerdasan telah mengungkapkan bahwa pola perkembangan mental dapat diramalkan seperti halnya pola perkembangan fisik. Hasil beberapa studi longitudinal meliputi berbagai pangsa (segmen) daur hidup sejak bayi hingga usia 50 tahun menunjukkan bahwa bagian utama dari pertumbuhan mental muncul pada saat bayi berkembang paling cepat, yaitu selama 16 hingga 18 tahun pertama. Juga terdapat pola perkembangan yang dapat diramalkan untuk berbagai fungsi 
kecerdasan, seperti daya ingat dan penalaran, yang merupakan kecerdasan

umumnya. Penelitian Therman telah menunjukkan bahwa sebagian terbesar anak-anak berbakat memang sesuai dengan kemampuannya.

Perkembangan

kecerdasan dipengaruhi oleh sejumlah faktor seperti kemampuan bawaan, suasana emosional, apakah seseorang didorong untuk melakukan kegiatan intelektual, apakah seseorang mempunyai dorongan intelektual yang kuat dan apakah seseorang mempunyai kesempatan untuk mengalami dan belajar. Betapapun banyaknya rangsangan yang diterima anak, mereka tidak dapat belajar sampai perkembangan mereka siap untuk melakukannya. Masih menurut Havighurst, matangnya kesiapan sebagai "saat untuk diajar" (teachable moment). Ketika badan sudah matang, masyarakat memintanya dan dirinya telah siap untuk menerima tugas tertentu, maka saat untuk diajar telah tiba. Usaha pengajaran akan terbuang percuma bila dilakukan sebelumnya dan akan membuahkan hasil yang memuaskan bila dilakukan pada saat yang tepat, ketika tugas memang harus dipelajari (Hurlock, 2000).

Seorang anak dari lahir memerlukan pelayanan yang tepat dalam pemenuhan kebutuhan pendidikan disertai dengan pemahaman mengenai karakteristik anak sesuai pertumbuhan dan per kembangannya akan sangat membantu dalam menyesuaikan proses belajar bagi anak dengan usia, kebutuhan, dan kondisi masing-masing, baik secara intelektual, emosional dan sosial. Sering kita mendengar anak-anak yang akan memasuki Sekolah Dasar diberikan beberapa tes ujian masuk. Mungkin saat mendengarnya orang tua akan berpikiran mempersiapkan kemampuan anaknya secara optimal. Khususnya kemampuan anak dalam menulis, membaca huruf dan kalau perlu sudah mampu berhitung. 
Faktor-faktor dalam kesiapan sekolah anak meliputi : 1) Kesehatan Fisik. baik. Kesehatan yang baik dengan asupan gizi yang seimbang sangat dibutuhkan untuk dapat menunjang kesiapan masuk sekolah. Anak yang sehat akan lebih mudah mencerna pengetahuan yang diajar kan serta bersosialisasi dengan lebih baik, tampil gesit dan bersemangat, baik dalam menerima informasi maupun dalam membina hubungan sosial dengan guru serta teman -temannya. 2) Usia. Beberapa ahli mengatakan bahwa faktor usia sangatlah penting untuk menentukan kesiapan anak masuk sekolah dasar. Menurut Janke, Comenius, Buhler dan Hetzer dalam buku Nijmeegse Schoolbekwaamheids Test menganggap usia 6 tahun sebagai usia yang cukup matang untuk sekolah. Pada usia ini umumnya anak telah memiliki perbendaharaan kata yang cukup banyak, memiliki kemampuan membayangkan seperti anak-anak seusianya, dapat mengemukakan secara verbal ide-ide dan pikiran-pikirannya serta organ-organ Kecerdasan/inteligensi merupakan kemampu

indra dan motorik telah terkoordinasi dengan an seorang anak dalam memahami instruksi verbal teoritis dan menyelesaikan tugastugas konkrit praktis dibandingkan dengan anak-anak seusianya. Anak-anak dengan tingkat kecerdasan yang berfungsi pada tahap rata-rata akan menyelesaikan tugas tugas tersebut secepat anak-anak seusianya. Adapun anak-anak yang memiliki tingkat kecerdasan tinggi akan menyelesaikan tugastugas tersebut secara lebih cepat dan sebaliknya anak-anak yang memiliki tingkat kecerdasan rendah akan melaksanakannya dengan lebih lambat. Dengan demikian untuk memasuki dunia sekolah yang memiliki program pembelajaran untuk usia tertentu, maka setidaknya seorang anak memiliki tingkat kecerdasan yang berfungsi pada tahap rata-rata. 4) Stimulasi Tepat. Faktor lingkungan terdekat dengan anak sangat berperan dalam menunjang kesiapan anak untuk memasuki sekolah dasar, 
sehingga potensi perkembangan anak yang dimiliki anak dapat berkembang secara optimal. Orangtua dan guru memegang peranan yang sangat penting dalam mengembangkan aspek-aspek yang sangat menunjang kesiapan anak untuk sekolah meliputi semua perkembangan baik perkembangan motorik kasar dan halus, perkembangan bahasa, perkembangan sosial, perkembangan kognisi dan perkembangan emosi anak. 5) Motivasi. Anak yang merasa bahagia biasanya memiliki motivasi baik untuk melakukan sesuatu, serta umumnya melakukan kegiatan didasari oleh tujuan tertentu (Kustimah, Abidin dan Kusumawati,2007).

Oleh sebab itu tes kesiapan sekolah terlihat perlu dilakukan, biasanya pada saat anak memasuki usia SD, disini mencakup entry skill yang dibutuhkan untuk mengatasi situasi belajar yang dihadapi di kelas 1. Meskipun tes ini mirip dengan tes kecerdasan, di sekolah dasar ini lebih menekankan kemampuan yang dianggap penting untuk belajar membaca, juga pada persyaratan berpikir numeric, dan kontrol sensorimotor yang dibutuhkan untuk belajar menulis. Fungsi-fungsi yang tercakup dalam tes kesiapan sekolah ini adalah diskriminasi penglihatan, pendengaran, perbendaharaan kata, konsep kuantitatif dan pengetahuan umum (Damayanti, 2016).

\section{Kesiapan Anak Menghadapi Sekolah}

Banyak definisi dan konseptualisasi kesiapan sekolah telah digunakan dalam beberapa dekade terakhir, namun dengan kemajuan terbaru dalam sains dan pengetahuan, konsensus yang berkembang tentang definisi telah muncul.

Banyaknya respon yang bervariasi mengenai pengertian kesiapan sekolah oleh responden. Orang tua biasanya menekankan keterampilan dan pengetahuan pra-akademik (Diamond, Reagan dan Bandyk 2000; UNICEF 2004), sementara guru sekolah dasar cenderung 
menekankan aspek sosial dan emosional (Docket dan Perry 2003). Variasi dalam penekanan ini menunjukkan bahwa berbagai keterampilan dan kemampuan perkembangan mencakup 'siap untuk sekolah'.

Menurut (Denton 2000; Schoen dan Nagle 2004) sikap terhadap pembelajaran, seperti kegigihan tugas, perhatian, kreativitas, inisiatif, rasa ingin tahu dan penyelesaian masalah, juga dikenal penting untuk kesiapan sekolah. Berdasarkan konsep-konsep ini, kesiapan sekolah adalah cara holistik dalam melihat kesiapan anakanak untuk sekolah. Tidak terbatas pada satu bidang pengembangan atau fungsi, kesiapan mencakup keterkaitan antara keterampilan dan perilaku di seluruh domain pengembangan dan pembelajaran (Unicef, 2012).

Kesiapan sekolah saat ini didefinisikan oleh tiga dimensi yang saling terkait: a) anak siap; b) sekolah siap pakai dan c) keluarga siap. Anak-anak, sekolah dan keluarga dianggap siap ketika mereka telah memperoleh dan c) keluarga siap. Anak-anak, sekolah dan keluarga dianggap siap ketika mereka telah memperoleh yang lancar. Misalnya, transisi anak ke sekolah, transisi sekolah untuk menerima anak-anak baru ke kelas 1, dan transisi keluarga untuk mengirim anak-anak mereka ke sekolah tepat waktu dan berinteraksi dengan sekolah Tiga dimensi dan fitur karakteristik ini diilustrasikan dan dijelaskan secara lebih rinci di bawah ini :

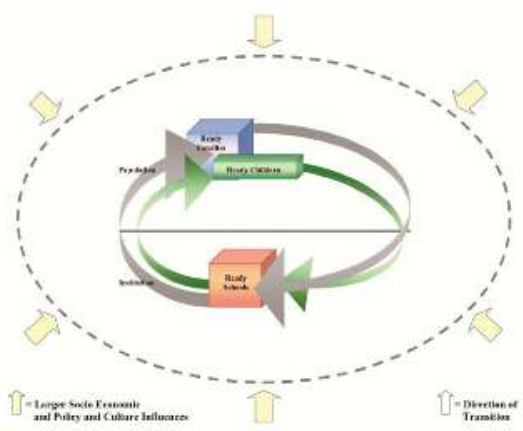

Figure 1: Building Competency/Capacity for Transition to School

Sumber: Unicef, 2012

Tiga dimensi kesiapan sekolah adalah:

(1) Anak siap, dengan fokus pada pembelajaran dan perkembangan anak.

(2) Sekolah siap pakai, dengan fokus pada lingkungan sekolah bersama 
dengan praktik-praktik yang

mendorong dan mendukung transisi

yang lancar untuk anak-anak ke

sekolah dasar dan memajukan dan

mempromosikan pembelajaran

semua anak

(3) Keluarga siap pakai, dengan fokus pada sikap dan keterlibatan orang tua dan pengasuh dalam pembelajaran dan pengembangan awal anak-anak mereka dan transisi ke sekolah. Ketiga dimensi itu penting dan harus bekerja bersama-sama, karena kesiapan sekolah adalah masa transisi yang membutuhkan antarmuka antara individu, keluarga dan sistem (Unicef, 2012).

Mengingat pentingnya "kesiapan sekolah" sebagai dasar kemampuan untuk mengikuti berbagai tuntutan kegiatan dan kurikulum sekolah dasar, maka telah berkembang suatu instrumen untuk mengukur kesiapan sekolah yang diukur melalui kematangan anak pada berbagai aspek perkembangan. Tes yang paling sering digunakan adalah N.S.T (Nijmeegse Schoolbekwaamheids Test). Tes ini merupakan alat ukur untuk mengetahui kematangan aspek-aspek yang menunjang kesiapan anak masuk Sekolah Dasar, yaitu yang meliputi kematangan dari aspek kognitif, motorik, dan juga sosial-emosi.

Terkait dengan kesiapan sekolah, Hurlock (1980) menyatakan bahwa kesiapan bersekolah terdiri dari kesiapan secara fisik dan psikologis, yang meliputi kesiapan emosi, sosial dan intelektual. Seorang anak dikatakan telah memiliki kesiapan fisik bila perkembangan motoriknya sudah matang, terutama koordinasi antara mata dengan tangan (visio-motorik) berkembang baik.

Adapun yang dimaksud dengan masing-masing aspek diatas adalah sebagai berikut :

Aspek kognitif yang dimaksud dalam kesiapan mengikuti pendidikan sekolah dasar tidak hanya sebatas tingkat 
kecerdasan. Namun juga dengan memperhatikan kematangan dari aspekaspek kognitifnya seperti ketajaman pengamatan, kemampuan persamanaanperbedaan, juga pemisahan figure \& ground yang menjadi dasar anak untuk melakukan seleksi dan memfokuskan perhatian. Aspek kognitif tersebut menjadi dasar bagi anak untuk memenuhi tuntutan pada berbagai bidang pelajaran, baik itu membaca, berhitung dan juga ketajaman dalam identifikasi dan mengkritisi suatu masalah.

Kematangan di bidang fisik, terutama motorik, menjadi modal bagi anak untuk mampu melakukan kegiatan di SD mulai dari tuntutan untuk mampu duduk dalam jangka waktu yang cukup lama, kemampuan menulis, menggambar, dll. Lebih lanjut lagi kematangan motorik menjadi dasar kenyamanan fisik anak yang pada akhirnya membantunya untuk dapat lebih mengendalikan perilaku, dan memfokuskan kegiatan pada satu tugas hingga tuntas.

Kematangan pada aspek emosi dan sosial memungkinkan anak untuk secara nyaman "terpisah" dari lingkungan rumah, terutama orang tua, dan mulai memperluas lingkup sosial pada konteks pertemanan, baik dengan sebaya, dan juga dengan orang dewasa lain, dalam hal ini guru. Kondisi ini juga menjadi dasar untuk mencapai kemandirian dalam penyelesaian tugas. Bahkan lebih lanjut lagi dapat memungkinkan anak untuk menjadi individu yang berani tampil dan mampu secara asertif menyatakan pendapat. Kematangan pada aspek ini juga memungkinkan anak untuk mengembangkan kepekaan dan rasa kebersamaan dengan orang lain (Kustimah, Abidin dan Kusumawati, 2007).

\section{Nijmeegse Schoolbekwaamheids}

Test (N.S.T.) disusun oleh Prof. F.J. Mönks, Drs. H. Rost dan Drs. N.H. Coffie, merupakan alat ukur untuk mengetahui 
kematangan aspek-aspek yang menunjang kesiapan anak masuk Sekolah Dasar. Test ini terdiri atas 10 subtes, dengan gambaran tes yang berisi gambar-gambar atau melengkapi gambar sekaligus jawabannya, yang masing -masing mengungkap kemampuan yang berbeda, yaitu: 1 . Subtes 1: Pengamatan bentuk dan kemampuan membedakan (vorm waarneming en onderscheidings vermogen); 2. Subtes 2: Motorik halus (fijne motoriek); 3. Subtes 3: Pengertian tentang besar, jumlah, dan perbandingan (begrip voor grootte hoeveelheid en verhoudingen); 4. Subtes 4: Pengamatan tajam (scherp waarnemen); 5.

Subtes 5: Kemampuan berpikir kritis (kritische waarneming); 6. Konsentrasi (taakspanning); 7. Subtes 7: Ingatan (geheugen); 8. Subtes 8: Pengertian objek dan penilaian situasi (object begrip en situatieboordeling); 9. Subtes 9: Menirukan cerita (weergeven van een verhaaltje); 10.Subtes 10: Menggambar orang (menstekening).
Menurut Monks, Rost, dan Coffie bahwa NST dikembangkan di Nijmegen Nederland merupakan pengolahan tes Gopinger dari Jerman yang digunakan untuk mengungkap kemampuan sekolah anak. Hal senada diungkapkan bahwa NST merupakan suatu alat tes yang digunakan untuk mengungkap kesiapan untuk masuk sekolah dasar, meliputi kesiapan fisik dan kesiapan psikis. Kesiapan psikis ini terdiri dari kemasakan emosi, sosial, dan intelektual. NST bersifat non verbal dan disajikan secara individual (Damayanti,2015).

Dapat disimpulkan bahwa kesiapan anak sekolah terdiri dari beberapa aspek, baik fisik maupun psikologis dan salah satu alat tes untuk mengukur kesiapan sekolah adalah Nijmeegse Schoolbekwaamheids Test (N.S.T) yang mengukur aspek-aspek kognitif, motorik halus dan motorik kasar, penilaian sosial, serta emosional. 


\section{Inteligensi}

Inteligensi bukan merupakan kata asli yang berasal dari bahasa Indonesia. Kata inteligensi adalah kata yang berasal dari bahasa latin yaitu "inteligensia" sedangkan kata "inteligensia" itu sendiri berasal dari kata inter dan lego, inter yang berarti diantara, sedangkan lego berarti memilih Sehingga inteligensi pada mulanya mempunyai pengertian kemampuan untuk memilih suatu penalaran terhadap fakta atau kebenaran.

Ada beberapa pengertian mengenai inteligensi yang akan penulis paparkan dari beberapa definisi inteligensi yang dikemukakan oleh beberapa ahli psikologi maupun pendidik diantaranya :

a) Menurut Alfred Binet (1857-1911) \& Theodore Simon, inteligensi terdiri dari tiga komponen, yaitu kemampuan untuk mengarah kan pikiran atau tindakan, kemampuan untuk mengubah arah tindakan bila tindakan itu telah dilaksanakan, dan kemampuan untuk mengritik diri sendiri (autocriticism).

b) Lewis Madison Terman pada tahun 1916 mendefi nisikan inteligensi sebagai kemampuan seseorang untuk berpikir secara abstrak. H. H. Goddard pada tahun 1946 mendefi nisikan inteligensi sebagai tingkat kemampuan pengalaman seseorang untuk menyelesaikan masalah-masalah yang dihadapi dan untuk mengantisipasi masalah- masalah yang akan datang.

c) V.A.C. Henmon mengatakan bahwa inteligensi terdiri atas dua faktor, yaitu kemampuan untuk memperoleh pengetahuan dan pengetahuan yang telah diperoleh. Baldwin pada tahun 1901 mendefinisikan inteligensi sebagai daya atau kemampuan untuk memahami. Edward Lee Thorndike (1874-1949) pada tahun 1913 men defi nisikan inteligensi sebagai kemampuan dalam memberikan respon yang baik dari pandangan kebenaran atau fakta. 
d) George D. Stoddard pada tahun 1941 mendefinisikan inteligensi sebagai kemampuan untuk memahami masalahmasalah yang bercirikan mengandung kesukaran, kompleks, abstrak, ekonomis, diarahkan pada suatu tujuan, mempunyai nilai sosial, dan berasal dari sumbernya.

e) Walters dan Gardber pada tahun 1986 mendefinisikan inteligensi sebagai suatu kemampuan atau serangkaian kemampuan-kemampuan yang memungkinkan individu memecahkan masalah, atau produk sebagai konsekuensi eksistensi suatu budaya tertentu. Flynn pada tahun 1987 mendefinisikan inteligensi sebagai kemampuan untuk berpikir secara abstrak dan kesiapan untuk belajar dari pengalaman.

f) George D. Stoddard pada tahun 1941 mendefinisikan inteligensi sebagai kemampuan untuk memahami masalahmasalah yang bercirikan mengandung kesukaran, kompleks, abstrak, ekonomis, diarah kan pada suatu tujuan, mempunyai nilai sosial, dan berasal dari sumbernya.

g) Walters dan Gardber pada tahun 1986 mendefinisikan inteligensi sebagai suatu kemampuan atau serangkaian kemampuan-kemampuan yang memungkinkan individu memecahkan masalah, atau produk sebagai konsekuensi eksistensi suatu budaya tertentu. Flynn pada tahun 1987 mendefinisikan inteligensi sebagai kemampuan untuk berpikir secara abstrak dan kesiapan untuk belajar dari pengalaman.

h) David Wechsler, intelegensi adalah kemampuan untuk bertindak secara terarah, berpikir secara rasional, dan menghadapi lingkungannya secara efektif. Secara garis besar dapat disimpulkan bahwa intelegensi adalah suatu kemampuan mental yang melibatkan proses berpikir secara 
rasional. Oleh karena itu, intelegensi tidak dapat diamati secara langsung, melainkan harus disimpulkan dari berbagai tindakan nyata yang merupakan manifestasi dari proses berpikir rasional itu.

i) Intelegensi atau kecerdasan diartikan dalam berbagai dimensi oleh para ahli.

Donald Stener, seorang Psikolog menyebut intelegensi sebagai suatu kemampuan untuk menerapkan pegetahuan yang sudah ada untuk memecahkan berbagai masalah. Tingkat intelegensi dapat diukur dengan kecepatan memecahkan masalahmasalah tersebut.

j) Intelegensi secara umum dapat juga diartikan sebagai suatu tingkat kemampuan dan kecepatan otak mengolah suatu bentuk tugas atau keterampilan tertentu. Kemampuan dan kecepatan kerja otak ini disebut juga dengan efektifitas kerja otak (Nur'aeni,2012).

\section{Faktor-faktor Yang Mempengaruhi}

Inteligensi

Perbedaan perkembangan inteli gensi antara individu yang satu dengan individu yang lainnya disebabkan karena adanya pengaruh beberapa faktor seperti :

\section{a) Faktor Bawaan atau Keturunan}

Penelitian membuktikan bahwa korelasi nilai tes IQ dari satu keluarga sekitar 0,50. Sedangkan di antara 2 anak kembar, korelasi nilai tes Iqnya sangat tinggi, sekitar 0,90. Bukti lainnya adalah pada. Anak yang di adopsi. IQ mereka berkorelasi antara 0,40 - 0,50 dengan ayah dan ibu yang sebenarnya, dan hanya $0,10-0,20$ dengan ayah dan ibu angkatnya. Selanjutnya bukti pada anak kembar yang dibesarkan secara terpisah, IQ mereka tetap berkorelasi sangat tinggi, walaupun mereka tidak pernah saling kenal.

b) Faktor Lingkungan

Walaupun ada ciri-ciri yang pada dasarnya sudah dibawa sejak lahir, 
ternyata lingkungan sanggup

menimbulkan perubahan-perubahan

yang berarti. Intelegensi tentunya tidak

bisa terlepas dari otak. Perkembangan

otak sangat dipengaruhi oleh gizi yang

dikonsumsi. Selain gizi, rangsangan-

rangsangan yang bersifat kognitif

emosional dari lingkungan juga

memegang peranan yang amat penting

(Nur'aeni,2012).

\section{Inteligensi dan IQ}

Orang seringkali menyamakan arti intelegensi dengan IQ, padahal kedua istilah ini mempunyai perbedaan arti yang sangat mendasar. Arti intelegensi sudah dijelaskan di depan, sedangkan IQ atau tingkatan dari Intelligence Quotient, adalah skor yang diperoleh dari sebuah alat tes kecerdasan. Dengan demikian, IQ hanya memberikan sedikit indikasi mengenai taraf kecerdasan seseorang dan tidak menggambarkan kecerdasan seseorang secara keseluruhan. Skor IQ mula-mula diperhitungkan dengan membandingkan umur mental (mental age) dengan umur kronologik (chronological age).

Bila kemampuan individu dalam memecahkan persoalan-persoalan yang disajikan dalam tes kecerdasan (umur mental) tersebut sama dengan kemampuan yang seharusnya ada pada individu seumur dia pada saat itu (umur kronologis), maka akan diperoleh skor 1. Skor ini kemudian dikalikan 100 dan dipakai sebagai dasar perhitungan IQ. Tetapi kemudian timbul masalah karena setelah otak mengalami kemasakan, tidak terjadi perkembangan lagi, bahkan pada titik tertentu akan terjadi penurunan kemampuan.

Pada tahun 1904, Alfred Binet dan Theodor Simon, 2 orang psikolog Perancis merancang suatu alat evaluasi yang dapat dipakai untuk mengidentifi kasi siswasiswa yang memerlukan kelas-kelas khusus (anak-anak yang kurang pandai). Alat tes itu dinamakan Tes Binnet-Simon. Tes ini kemudian direvisi pada tahun 1911. 
Tahun 1916, Lewis Terman, disebut teori faktor (Factor Theory of seorang psikolog dari Amerika Intelligence). Alat tes yang dikembangkan mengadakan banyak perbaikan dari Tes menurut teori faktor ini adalah WAIS Binet-Simon. Sumbangan utamanya adalah menetapkan indeks numerik yang menyatakan kecerdasan sebagai rasio (perbandingan) antara mental age dan chronological age. Hasil perbaikan ini disebut Tes Stanford_binet. Indeks seperti ini sebetulnya telah diperkenalkan oleh psikolog Jerman yang bernama William Stern, yang kemudian dikenal dengan Intelligence Quotient atau IQ. Tes Stanford_Binet ini banyak digunakan untuk mengukur kecerdasan anak-anak sampai usia 13 tahun.

Salah satu reaksi atas Tes BinetSimon atau Tes Stanford-Binet adalah bahwa tes itu terlalu umum. Seorang tokoh dalam bidang ini, Charles Spearman mengemukakan bahwa inteligensi tidak hanya terdiri dari satu faktor yang umum saja (General factor), tetapi juga terdiri dari faktor-faktor yang lebih spesifik. Teori ini (Wechsler Adult Intelligence Scale) untuk orang dewasa, dan WISC (Wechsler Intelligence Scale for Children) untuk anak-anak.

Salah satu alat ukur inteligensi yang banyak digunakan di Indonesia adalah WISC. Alat ukur ini diperkenalkan pertama kali oleh Dr. Weschler dan telah mengalami beberapa revisi. Untuk yang diadaptasi di Indonesia merupakan adaptasi skala asli yang telah direvisi (penulis menduga ini merupakan bentuk revisi ke III yang dilakukan pada tahun 1980an). Seperti namanya yang terdapat kata children, alat tes ini diperuntukkan bagi anak berusia 5-15 tahun (Untuk usia diatasnya ada alat tes WAIS). Skala WISC terbagi atas 2 kelompok tes yang disebut kelompok Verbal dan Kelompok Performance. Masing-masing kelompok terdapat 6 tes yang dikelompokkan sebagai 
berikut : Kelompok Verbal : Informasi,

Pemahaman, Berhitung, Persamaan,

Perbedaharaan Kata, Rentangan Angka

(tambahan). Kelompok Performance :

Melengkapi Gambar, Mengatur Gambar,

Rancangan Balok, Merakit Objek, Simbol,

Mazes (tambahan) (Nur'aeni,2012).

Tes WISC merupakan tes

inteligensi yang biasa digunakan untuk

mengukur taraf kecerdasan anak usia 5

tahun hingga 15 tahun. Tes WISC memiliki

kemampuan untuk mendeskripsikan

berbagai aspek kecerdasan anak, seperti

wawasan dan minat pengetahuan, daya

konsentrasi dan daya ingat jangka pendek,

berbagai kemampuan, seperti: bahasa,

matematika, berpikir logis dan abstrak,

visual motoric coordination, visual

perception organization, visual-spatial

relationship dan field dependence, adaptasi

terhadap lingkungan dan pemahaman

terhadap norma-norma sosial (berkaitan

dengan antisipasi masalah sosial dan

ketrampilan sosial), dan kreativitas.
Beberapa penelitian telah menggunakan tes WISC untuk mengungkap gejalagejala gangguan klinis pada anak, seperti: main brain disfunction /brain damage, emotional disturbance, anxiety,delinquency, learning disabilities, dan lain-lain (Sattler, 1978). Dengan mempertimbangkan kemampuan tes WISC mendeskripsikan berbagai aspek kecerdasan anak dan tes WISC telah digunakan dalam berbagai penelitian, penulis tidak ragu untuk mempelajari karakteristik hasil tes inteligensi anak dengan GPPH dari tes WISC. Selain itu penulis juga mempertimbangkan adaptasi dan standarisasi tes WISC telah dilakukan di Indonesia. Dengan demikian, keuntungan menggunakan tes WISC jauh lebih banyak sehingga dapat mengatasi kelemahan pelaksanaan administrasi tes WISC, yang harus dilakukan secara individual dan membutuhkan waktu dan tenaga yang lebih banyak. Penulis semakin yakin pula dalam menggunakan tes WISC setelah melakukan pengamatan di 
lapangan. Pengamatan di lapangan pengenalan fisik yaitu berdasarkan dijumpai bahwa anak perbedaan struktur anatomi tubuh laki-laki (http://journal.ugm.ac.id/jpsi/article/view/7 dan perempuan. Perbedaan utama antara 087, diakses tanggal 13 Mei 2016).

struktur anatomi laki-laki dan perempuan adalah terletak pada fungsi dan struktur

\section{Jenis Kelamin}

a) Pengertian Jenis Kelamin

Menurut Gulo (1992), jenis kelamin atau sexe adalah kualitas yang menentukan seseorang adalah pria dan wanita. Oleh karena itu, Champlin (2002), mengatakan jenis kelamin adalah perbedaan yang khas antara perempuan dan laki-laki baik secara fisik maupun mental sedangkan menurut Ward (Damayanti, 2012), mengatakan jenis kelamin adalah peran seks yang ditentukan secara budaya mencerminkan perilaku dan sikap yang umumnya disetujui sebagai maskulin dan feminan suatu budaya tertentu. Jenis kelamin manusia terbagi dua yaitu jenis kelamin laki-laki dan jenis kelamin perempuan. Pembagian manusia dari jenis kelamin ini pada dasarnya dilakukan sebagai cara organ-organ reproduksi/regenerasi. Pada akhirnya perbedaan jenis kelamin menyebabkan suatu perbedaan yang cukup tajam terlihat secara fisik. Perbedaan jenis kelamin pada awalnya hanya merupakan perbedaan fisik semata, setelah sekian lama sepanjang sejarah akhirnya memberikan dampak yang besar pada perbedaan sikap mental, psikologi dan emosional kaum laki-laki maupun perempuan (Indonesia Siu Tao Com, 26 Mei 1999).

Dalam buku Wade dan Tavris (2007) Budaya dan agama berbeda skema dalam membedakan peran Laki-laki dan Perempuan. Misalnya, pendidikan setara bagi Laki-laki dan Perempuan tidak dipandang sebagai hal yang penting, walaupun ada hukum yang mewajibkan pendidikan minimal bagi semua orang. 
Dalam dunia yang semakin cepat perempuan tersebut maka dapat

berkembang, masyarakat terhadap pria dan

wanita terus bergeser. Hasilnya,

perkembangan gernder menjadi proses

seumur hidup, di mana skema gender, sikap, dan prilaku berubah seiring dengan bertambahnya pengalaman baru dan perubahan masyarakat. Perilaku mereka dibentuk oleh gabungan dari faktor hormon, gen, skema kognitif, pendidikan dari orang tua dan lingkungan sosial, tradisi agama dan budaya, serta pengalaman.

Menurut Broverman dkk (Dagun, 1990), sifat-sifat kaum laki-laki antara lain adalah agresif, bebas, rasional, objektif, tidak mudah terpengaruh, aktif, suka kompetisi, tidak suka ketergantungan, dan ambisius. Sebaliknya sifat-sifat wanita antara lain adalah pasif, kurang bebas, emosional, subjektif, mudah terpengaruh, tidak suka kompetisi, kurang percaya diri, dan tidak ambisius. Maka berdasarkan perbedaan sifat antara laki-laki dan disimpulkan bahwa sifat-sifat laki-laki lebih ambisius, lebih agresif, lebih suka berkompetisi, dan memiliki rasa percaya diri yang lebih tinggi daripada perempuan, membawa pada sesuatu asumsi bahwa tingkat aspirasi laki-laki lebih tinggi daripada tingkat aspirasi perempuan.

b) Ciri-ciri Peran Jenis Kelamin

Peran jenis kelamin laki-laki memiliki ciri-ciri yaitu mendominasi segala sesuatu seperti terlihat dalam perilaku agresif dan asertif, kepuasan diri hanya lewat prestasi sendiri, mempertimbangkan diri pertama-tama dalam segala situasi, karena superior, mengharapkan dilayani perempuan, sebagai pencari nafkah, pembuat dan pengambil keputusan sedangkan peran jenis kelamin perempuan mempunyai ciriciri patuh dalam segala situasi seperti terlihat dalam kesediaan untuk menuruti keinginan dan melayani laku-laki, mengekspresikan emosi, memberikan 
kehangatan dalam hubungan sosial di rumah dan di luar, berorientasi kepada orang lain, mempertimbangkan orang lain sebelum dirinya, dan memiliki peran utama yaitu mengatur rumah tangga dan mengasuh anak dan memberikan laki-laki yang mengambil keputusan (Hurlock, 1993).

Menurut Broverman (Damayanti, 2012), ada perbedaan sifat antara peran jenis kelamin laki-laki dan peran jenis kelamin perempuan. Peran jenis kelamin laki-laki memiliki sifat-sifat tidak emosional, hampir memendamkan emosi, sangat objektif, tidak mudah terpengaruh, sulit menangis, sangat percaya diri, mudah memisahkan pikiran dan perasaan, tidak ada ketergantungan, sangat sedikit kebutuhan keamanan dan tidak meluapkan perasaan. Lebih lanjut dikatakan peran jenis kelamin perempuan memiliki sifatsifat sangat emosional, tidak memendam emosi, sangat objektif, tertutup, sangat tergantung, mudah menangis, tidak percaya diri, sangat lembut, sangat membutuhkan keamanan, serta mudah meluapkan perasaan. Menurut Wiliams dan Mest dalam Berry,dkk. (1996), ciri-ciri yang dikaitkan dengan laki-laki adalah agresif, aktif, ambisius, angkuh, berdaya cipta, berpikiran jernih, berprasangka, sungguhsungguh, bijaksana, cerdik, logis, opurtunitis, rasional, tegas, penutut, berkemauan, lemah, emosional, peka, pencemas, penakut, tergantung, penurut, hangat, lembut dan menyenangkan Penelitian ini bertujuan untuk mengetahui perbedaan kesiapan anak masuk sekolah dasar ditinjau dari tingkat inteligensi dan jenis kelamin.

\section{METODE}

Penelitian ini dilaksanakan di TK Al-Jabbar dan TKIT Robbani di kota Malang yang akan masuk sekolah dasar.

Subjek penelitian ini berjumlah 76 orang anak. Penelitian ini menggunakan penelitian kuantitatif dengan menggunakan 
metode purposive random sampling yaitu sampel diambil dari subjek yang sudah memiliki ciri-ciri atau sifat-sifat populasi yang sudah diketahui sebelumnya. Adapun ciri-cirinya adalah sebagai berikut : 1) murid murni bukan pindahan; 2) anak TK kelas B.

\section{Instrumen Penelitian}

Instrumen yang digunakan dalam penelitian ini adalah Untuk kesiapan bersekolah menggunakan Nijmeegse Schoolbekwaamheids Test (N.S.T.) telah menetapkan tiga standar yaitu belum matang, ragu, dan matang sedangkan untuk tingkat inteligensi menggunakan tes WISC (Wechler Intelegence Scale for Children), Jenis kelamin didapat dari data siswa.

\begin{tabular}{|c|c|c|}
\hline \multirow{2}{*}{$\mathrm{N}$} & Valid & 76 \\
\hline & Missing & 0 \\
\hline Mean & & 2,3684 \\
\hline Median & & 3,0000 \\
\hline Mode & & 3,00 \\
\hline Minimum & & 1,00 \\
\hline Maximum & & 3,00 \\
\hline
\end{tabular}

Berdasarkan hasil tes NST tersebut maka dapat dikategorikan sebagai berikut:

\section{Teknik Analisis Data}

Data penelitian dianalisis dengan teknik Uji Friedman Test.

\section{HASIL DAN PEMBAHASAN}

\section{Hasil}

Penelitian ini digunakan untuk mengetahui perbedaan kesiapan anak masuk sekolah dasar ditinjau dari tingkat inteligensi dan jenis kelamin di TK AlJabbar dan TKIT Robbani. Hasil penelitian tersebut dideskripsikan sebagai berikut:

\section{Deskripsi Hasil Tes NST}

Berdasarkan hasil penelitian dari 76 anak diperoleh hasil statistik penelitian untuk kesiapan sekolah dengan menggunakan NST (Nijmeegse Schoolbekwaamheids Test) sebagai berikut:

Tabel 2. Hasil Tes NST Kesiapan Sekolah

\begin{tabular}{|c|c|c|c|c|c|}
\hline & & $\begin{array}{r}\mathrm{Fr} \\
\text { equen } \\
\text { cy }\end{array}$ & $\begin{array}{r}P \\
\text { ercent }\end{array}$ & $\begin{array}{c}\text { Val } \\
\text { id } \\
\text { Percen } \\
t\end{array}$ & $\begin{array}{l}\text { Cumula } \\
\text { tive Percent }\end{array}$ \\
\hline \multirow{8}{*}{ Valid } & & 1 & 2 & 22 & \multirow{2}{*}{22,4} \\
\hline & belum siap & 7 & 2,4 & 4 & \\
\hline & siap & 1 & 1 & 18, & \multirow{2}{*}{40,8} \\
\hline & & 4 & 8,4 & 4 & \\
\hline & siap namun & 4 & 5 & 59, & \multirow[b]{2}{*}{100,0} \\
\hline & perlu & 5 & 9,2 & 2 & \\
\hline & \multirow[b]{2}{*}{ Total } & 7 & 1 & 10 & \\
\hline & & 6 & 00,0 & 0,0 & \\
\hline & & & & $\begin{array}{l}\text { P-ISSN } \\
\text { E-ISSN }\end{array}$ & $\begin{array}{l}0853-8050 \\
2502-6925\end{array}$ \\
\hline
\end{tabular}


Apabila ditampilkan dalam bentuk grafik dapat dilihat pada gambar di bawah ini :

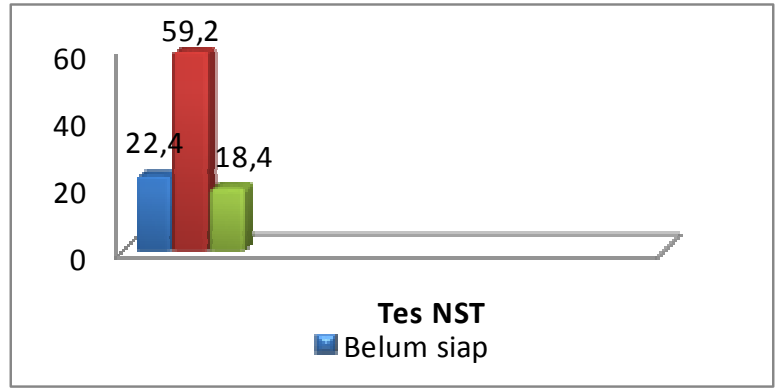

Gambar 1. Grafik Hasil Tes NST

Berdasarkan dari tabel dan gambar diatas diketahui kesiapan sekolah dengan menggunakan NST (Nijmeegse Schoolbekwaamheids Test) didapatkan hasil sebagai berikut: pada pemeriksaan terhadap 76 anak di TK Islam Restu Ibu dan TK Islam Terpadu Robbani. Didapatkan hasil bahwa terdapat 14 $(18,4 \%)$ siswa memiliki kesiapan untuk mengikuti proses belajar di sekolah, 45 $(59,2 \%)$ siswa belum sepenuhnya siap sedangkan $17 \quad(22,4 \%)$ siswa belum memiliki kesiapan untuk mengikuti proses belajar di sekolah.

\section{Deskripsi Hasil Tingkat Kecerdasan}

Berdasarkan hasil penelitian dari 76 anak diperoleh hasil statistik penelitian untuk tingkat kecerdasan sebagai berikut :

Tabel 3. Hasil Analisis Statistik Tingkat

\begin{tabular}{|c|c|c|}
\hline \multicolumn{3}{|c|}{ Kecerdasan } \\
\hline$N$ & Valid & 76 \\
\hline & Missing & 0 \\
\hline Mean & & 2,6447 \\
\hline Median & & 2,0000 \\
\hline Mode & & 2,00 \\
\hline Minimum & & 1,00 \\
\hline Maximum & & 4,00 \\
\hline
\end{tabular}

Berdasarkan hasil tes WISC tersebut maka dapat dikategorikan sebagai berikut :

\begin{tabular}{|c|c|c|c|c|c|}
\hline & & $\begin{array}{r}F \\
\text { reque } \\
\text { ncy }\end{array}$ & $\begin{array}{c}{ }^{P} \\
\text { erce } \\
\text { nt }\end{array}$ & $\begin{array}{c}\text { Val } \\
\text { id } \\
\text { Percent }\end{array}$ & $\begin{array}{l}\text { Cumulativ } \\
\text { e Percent }\end{array}$ \\
\hline \multirow{5}{*}{ Valid } & $\begin{array}{l}\text { dibawah rata- } \\
\text { rata }\end{array}$ & 4 & 5,3 & 5,3 & 5,3 \\
\hline & \multirow{3}{*}{$\begin{array}{l}\text { rata-rata } \\
\text { diatas ra } \\
\text { rata } \\
\text { superior }\end{array}$} & 37 & 48,7 & 48,7 & 53,9 \\
\hline & & 17 & 22,4 & 22,4 & 76,3 \\
\hline & & 18 & 23,7 & 23,7 & 100,0 \\
\hline & Total & 76 & 100,0 & 100,0 & \\
\hline
\end{tabular}

Apabila ditampilkan dalam bentuk grafik dapat dilihat pada gambar di bawah ini :

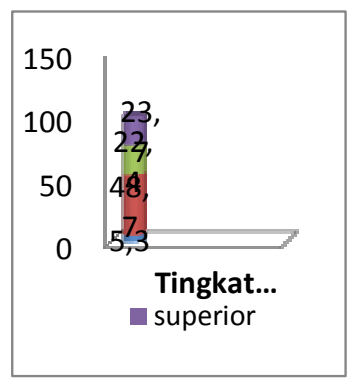

Gambar 2. Grafik Hasil Tingkat Kecerdasan 
Berdasarkan dari tabel dan gambar diatas diketahui tingkat kecerdasan anak di TK Islam Restu Ibu dan TK Islam Terpadu Robbani. Didapatkan hasil bahwa terdapat $4(5,3 \%)$ siswa berada pada kategori dibawah rata-rata, $37(48,7 \%)$ siswa berada pada kategori rata-rata, $17(22,4 \%)$ siswa berada pada kategori diatas rata-rata, 18 $(23,7 \%)$ siswa berada pada kategori superior.

\section{Deskripsi Hasil Jenis Kelamin}

Berdasarkan hasil penelitian dari 76 anak diperoleh hasil statistik penelitian untuk tingkat kecerdasan sebagai berikut :

Tabel 5. Hasil Analisis statistik Jenis Kelamin

\begin{tabular}{llr}
\hline $\mathrm{N}$ & Valid & 76 \\
Mean & Missing & 0 \\
Median & & 1,4868 \\
Mode & 1,0000 \\
Minimum & 1,00 \\
Maximum & 1,00 \\
\hline
\end{tabular}

Berdasarkan hasil penggolongan jenis kelamin tersebut maka dapat dikategorikan sebagai berikut :
Tabel 6. Hasil Penggolongan Jenis Kelamin

\begin{tabular}{ccrrrr}
\hline & $\begin{array}{c}\text { Fr } \\
\text { equen } \\
\text { cy }\end{array}$ & $\begin{array}{r}\text { P } \\
\text { ercent }\end{array}$ & $\begin{array}{c}\text { Valid } \\
\text { Percent }\end{array}$ & $\begin{array}{c}\text { Cum } \\
\text { ulative } \\
\text { Percent }\end{array}$ \\
\hline \multirow{4}{*}{ Valid } & perempua & 3 & 5 & 51,3 & 51,3 \\
& laki-laki & 9 & 1,3 & & \\
& Total & 7 & 8,7 & 48,7 & 100,0 \\
& 7 & 1 & & \\
\hline
\end{tabular}

Apabila ditampilkan dalam bentuk grafik dapat dilihat pada gambar di bawah ini :

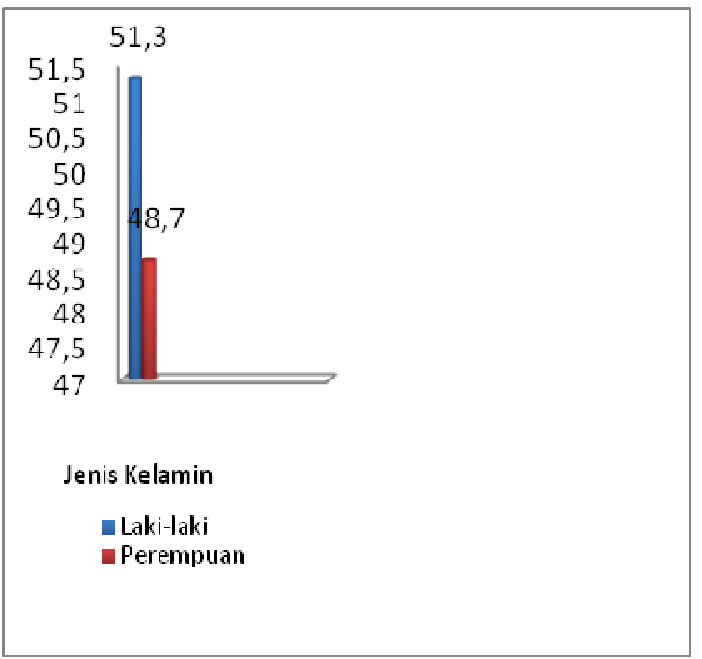

Gambar 3. Grafik Penggolongan Jenis Kelamin

\section{Uji Normalitas}

Pengujian normalitas mengunakan uji Kolmogorof-Sminorv. Dalam uji ini akan menguji hipotesis sampel berasal dari populasi berdistribusi normal, untuk menerima atau menolak hipotesis dengan membandingkan harga Asymp. Sig dengan 0,05. Kriterianya Menerima hipotesis apabila Asymp. Sig lebih besar dari 0,05, 
apabila tidak memenuhi keriteria tersebut maka hipotesis ditolak.

Tabel 7. Hasil Perhitungan Uji Normalitas

\begin{tabular}{|c|c|c|c|c|c|c|}
\hline & \multicolumn{3}{|c|}{$\begin{array}{l}\text { Kolmogorov- } \\
\text { Smirnov }^{\mathrm{a}}\end{array}$} & \multicolumn{3}{|c|}{ Shapiro-Wilk } \\
\hline & $\begin{array}{l}\text { Statis } \\
\text { tic }\end{array}$ & df & Sig. & $\begin{array}{l}\text { Statis } \\
\text { tic }\end{array}$ & df & Sig. \\
\hline $\begin{array}{l}\text { Standardize } \\
\text { d Residual } \\
\text { for } \\
\text { kesiapan_se } \\
\text { kolah }\end{array}$ & $\begin{array}{r}3 \\
69\end{array}$ & $\begin{array}{l}7 \\
6\end{array}$ & $\begin{array}{r}, 0 \\
00\end{array}$ & $\begin{array}{r}6 \\
94\end{array}$ & $\begin{array}{l}7 \\
6\end{array}$ & $\begin{array}{l}, 0 \\
00\end{array}$ \\
\hline $\begin{array}{l}\text { Standardize } \\
\text { d Residual } \\
\text { for } \\
\text { tingkat_kec } \\
\text { erdasan }\end{array}$ & $\begin{array}{r}3 \\
01\end{array}$ & $\begin{array}{l}7 \\
6\end{array}$ & $\begin{array}{l}, 0 \\
00\end{array}$ & $\begin{array}{r}, 8 \\
19\end{array}$ & $\begin{array}{l}7 \\
6\end{array}$ & $\begin{array}{l}, 0 \\
00\end{array}$ \\
\hline $\begin{array}{l}\text { Standardize } \\
\mathrm{d} \text { Residual } \\
\text { for } \\
\text { jenis_kelam } \\
\text { in }\end{array}$ & $\begin{array}{r}3 \\
47\end{array}$ & $\begin{array}{l}7 \\
6\end{array}$ & $\begin{array}{l}, 0 \\
00\end{array}$ & $\begin{array}{r}, 6 \\
36\end{array}$ & $\begin{array}{l}7 \\
6\end{array}$ & $\begin{array}{l}, 0 \\
00\end{array}$ \\
\hline
\end{tabular}

Dari tabel di atas harga Asymp.

Sig dari variabel semuanya lebih kecil dari 0,05 maka hipotesis yang menyatakan sampel berdasarkan dari populasi yang berdistribusi normal ditolak. Dari keterangan tersebut, maka data variabel dalam penelitian ini tidak dapat dianalisis menggunakan pendekatan statistik parametrik namun menggunakan pendekatan statistik non parametrik.

\section{Analisis Data}

Analisis data yang digunakan untuk menjawab hipotesis yang diajukan yaitu adakah perbedaan kesiapan anak masuk sekolah dasar ditinjau dari tingkat inteligensi dan jenis kelamin menggunakan uji Friedman Test. Uji Friedman ini dipakai sebagai alternatif dari Uji Repeated Measures Anova dalam statistik parametrik, hanya jika nilai Standardized Residual dari salah satu atau seluruh sampel data tidak berdistribusi normal. Oleh karena merupakan bagian dari statistik non parametrik, maka dalam $U j i$ Friedman ini tidak ada persyaratan khusus untuk nilai Standardized Residual dari sampel data yang dipakai harus berdistribusi normal.

Tabel 7. Hasil uji Friedman Test Kesiapan Anak Masuk Sekolah Dasar, Tingkat Kecerdasan dan Jenis Kelamin

\begin{tabular}{lr}
\multicolumn{2}{c}{ Ranks } \\
\hline & Mean Rank \\
\hline kesiapan sekolah & 2,26 \\
tingkat kecerdasan & 2,38 \\
jenis kelamin & 1,36 \\
\hline
\end{tabular}

\begin{tabular}{lr}
\multicolumn{2}{c}{ Test Statistics $^{\mathbf{a}}$} \\
\hline $\mathrm{N}$ & 76 \\
$\mathrm{C}$ Chi-Square & 58,106 \\
$\mathrm{df}$ & 2 \\
Asymp. Sig. &, 000 \\
\hline \multicolumn{2}{l}{ a. Friedman Test }
\end{tabular}

Hasil uji Friedman, nilai chi-square sebesar 58,106 . Sementara nilai chi-square 
Tabel adalah 5,991. Nilai $\mathrm{df}=2 \quad(\mathrm{k}-1), \quad$ perkembangan motoriknya sudah matang, dimana $\mathrm{k}$ adalah banyaknya kelompok terutama koordinasi antara mata dengan sampel yaitu karena nilai chi-square Hitung $58,106>$ chi-square Tabel 5,991, maka bahwa Ha diterima atau dengan kata lain ada perbedaan rata-rata kesiapan anak masuk sekolah dasar ditinjau dari tingkat kecerdasan dan jenis kelamin. Dengan demikian dapat disimpulkan bahwa tingkat kecerdasan dan jenis kelamin saling berinteraksi dalam membentuk kesiapan anak masuk sekolah dasar.

Dari hasil penelitian diperoleh bahwa hipotesa terbukti kebenarannya. Dengan demikian berarti ada perbedaan kesiapan anak masuk sekolah dasar ditinjau dari Tingkat Kecerdasan dan Jenis Kelamin.

Hal ini didukung oleh Hurlock (1980) menyatakan bahwa kesiapan bersekolah terdiri dari kesiapan secara fisik dan psikologis, yang meliputi kesiapan emosi, sosial dan intelektual. Seorang anak dikatakan telah memiliki kesiapan fisik bila 
pembelajaran untuk usia tertentu, maka setidaknya seorang anak memiliki tingkat kecerdasan yang berfungsi pada tahap ratarata. Selain itu di dalam jurnal yang ditulis oleh Kustimah dan Kusumawati, (2007) bahwa aspek kognitif yang dimaksud dalam kesiapan mengikuti pendidikan sekolah dasar tidak hanya sebatas tingkat kecerdasan. Namun juga dengan memperhatikan kematangan dari aspekaspek kognitifnya seperti ketajaman pengamatan, kemampuan persamanaanperbedaan, juga pemisahan figure \& ground yang menjadi dasar anak untuk melakukan seleksi dan memfokuskan perhatian. Aspek kognitif tersebut menjadi dasar bagi anak untuk memenuhi tuntutan pada berbagai bidang pelajaran, baik itu membaca, berhitung dan juga ketajaman dalam identifikasi dan mengkritisi suatu masalah.

Selain tingkat kecerdasan, menurut Broverman (Damayanti, 2012), ada perbedaan sifat antara peran jenis kelamin laki-laki dan peran jenis kelamin perempuan. Peran jenis kelamin laki-laki memiliki sifat-sifat tidak emosional, hampir memendamkan emosi, sangat objektif, tidak mudah terpengaruh, sulit menangis, sangat percaya diri, mudah memisahkan pikiran dan perasaan, tidak ada ketergantungan, sangat sedikit kebutuhan keamanan dan tidak meluapkan perasaan. Lebih lanjut dikatakan peran jenis kelamin perempuan memiliki sifatsifat sangat emosional, tidak memendam emosi, sangat objektif, tertutup, sangat tergantung, mudah menangis, tidak percaya diri, sangat lembut, sangat membutuhkan keamanan, serta mudah meluapkan perasaan. Hal senada juga disampaikan oleh Wade dan Tavris Garry (2007) budaya dan agama berbeda skema dalam membedakan peran Laki-laki dan Perempuan. Misalnya, pendidikan setara bagi Laki-laki dan Perempuan tidak dipandang sebagai hal yang penting, walaupun ada hukum yang mewajibkan 
pendidikan minimal bagi semua orang.

Dalam dunia yang semakin cepat berkembang, masyarakat terhadap pria dan wanita terus bergeser. Hasilnya, perkembangan gernder menjadi proses seumur hidup, di mana skema gender, sikap, dan prilaku berubah seiring dengan bertambahnya pengalaman baru dan perubahan masyarakat. Perilaku mereka dibentuk oleh gabungan dari faktor hormon, gen, skema kognitif, pendidikan dari orang tua dan lingkungan sosial, tradisi agama dan budaya, serta pengalaman.

\section{DAFTAR PUSTAKA}

Damayanti, Andia Kusuma (2015). Kesiapan Anak Masuk Sekolah Dasar Ditinjau Dari Pola Asuh Orang Tua. Jurnal Psikovidya. Volume 20. No.2 - Desember 2016. Universitas Wisnuwardhana Malang.

Damayanti, Andia Kusuma (2016).

Kesiapan Anak Masuk Sekolah Dasar Ditinjau Dari Dukungan Keluarga dan Motivasi Belajar. Jurnal Psikovidya. Volume 20. No.1
- April 2016. Universitas Wisnuwardhana Malang.

Fasli J. (2002) Pendidikan Anak Dini Usia, pendidikan yang mendasar. J PADU.;1:4-8.

Garry, Wade Travis (2016). Psikologi. Jakarta. Erlangga

Haditono, S.R. (1986). Pengasuhan Anak Menuju Kesiapan Masuk SD. Yogyakarta: Fakultas Psikologi UGM

Hurlock, Elizabeth B (1980). Perkembangan Anak. Jakarta: Erlangga

Jurnal PSIKOLOGIA (2005). Kesiapan bersekolah ditinjau dari jenis pendidikan pra sekolah anak dan tingkat pendidikan orangtua. Vol.I. no. 1 , Juni.

Kustimah, Fitri Ariyanti Abidin dan Dian Kusumawati (2007). Gambaran Kesiapan Anak Masuk Sekolah Dasar Dtinjau dari Hasil Test NS (Nijmeegse Schoolbekwaamheids Test). Bandung: Universitas Padjadjaran.

http://www.pustaka.unpad.ac.id. , , diakses tgl 10-06-2013.

Monks dkk. 2004. Psikologi Perkembangan Pengantar Dalam Berbagai Bagiannya. Gadjah Mada University Press. Yogyakarta. 
Monks FJ, Knoers AMP, Haditono SR. 2011. Psikologi perkembangan pengantar dalam berbagai bagiannya. Yogjakarta: Universitas J Indon Med Assoc, 61(9).

Nur'aeni. (2012), Tes Inteligensi.Purwokerto:UMP Press

Soemanto, W. (2003). Psikologi Pendidikan. Jakarta : PT. Rineka Cipta.

Sulistiyaningsih, W. (2005). Kesiapan Bersekolah Anak Ditinjau Dari Jenis Pendidikan Pra Sekolah Anak dan Tingkat Pendidikan Orangtua. Jurnal Psikologia. Volume 01 - Juni 2005. Universitas Sumatera Utara.

Syarief H. (2002) Pengembangan anak dini usia memerlukan keutuhan. J PADU.1:9-22.

Woelan, H. (2010). Uji Validitas dan Reliabilitas Tes NST. http://www.adln.lib.unair.ac.id.

Diakses 24-08-2013. Jurnal Psikologi Universitas Muria Kudus. (http://journal.ugm.ac.id/jpsi/article/v iew/7087, diakses tanggal 13

November 2018)

(http://personalityplus.blogspot.com/2004/

07/lahirnya-empat-karakter-

dasar.html diakses 10 November $\underline{2018)}$.

(http://www.telaga.org/ringkasan.php?kepr ibadian.htm diakses 11 November 2018).

(http://rimaold.blog.friendster.com/2006/0

1/mengenal-temperamenroma-721-

26/ diakses 07 November 2018).

(http://dict.die.net/personality/personality diakses 11 November 2018).

(www.parenting.co.id) 
